\title{
Integration of SERVQUAL Model with Quality Function Deployment to enhance Library's Service Quality
}

\author{
Nantapatr Vorasaiharit ${ }^{1}$, and Natcha Thawesaengskulthai ${ }^{2}$
}

\begin{abstract}
Advance technology and change in student behavior cause dissatisfaction to old style library and service. Hence, there is a need in new library service and infrastructure which the new design require right match to vibrant new student lifestyle. This study is to propose a methodology to capture customer requirements and translate them to technical requirement and propose appropriate solution to the needs using case study at the Engineering Faculty library of Chulalongkorn University. This study integrates SERVQUAL model and Quality Function Deployment (QFD) for this design purpose. Nineteen questions were created in Likert Scale to measure customer expectation and perception. Mean difference between expectation score and perception score were calculated, analyzed and tested their statistically significant at $95 \%$ confident interval. From five dimensions of SERVQUAL, there are 3 dimensions that analysis confirms statistically significant. Highest score of mean difference is tangible dimension with mean difference -0.61 . The second is Reliability with mean difference -0.22 and the last one is Empathy with -0.14 score. House of Quality is in charge of translating customer requirement to technical requirement as a way to design new library. Attractive qualities obtained from HOQ are (1) online searching and borrowing book or journal program. (2) Increase facilities like plug, Wi-Fi stability and speed. (3) Library has books or journal online reservation program for loan.
\end{abstract}

Keywords-SERVQUAL, Library service, Quality Function deployment, QFD, House of Quality

\section{INTRODUCTION}

$\mathrm{I}^{\mathrm{N}}$ $\mathrm{N}$ early 1990s, the digital world started to replace the library silently as information provider. Google has developed Google Scholar emphasize menace to existence of building library However digital world will not take over present libraries but libraries need to change their content, services, restructuring the organizational design and physical layout[1],[2]. The truth is behavior of student has changed. Generation Y students are high achievers, ambitious [3] and multitaskers, doing activities simultaneously plus working time of them may over midnight or later which most libraries have already closed [4]. Changed behavior will leads two major to Thai academic libraries [5]. First is digital environment which become vital part of human life and second is the increasing of competitor which is not only library in other university but learning center or coffee shop also. In order to survive, their service must be improved.

Nantapatr Vorasaoharit is Master Student, Chulalongkorn University, Thailand.
Above paragraphs point out necessity of adaptation, engineering faculty library of Chulalongkorn University face similar problems as others. Students require many services to support their study and prefer using coffee shop nearby university. Because lacking of library utilities such as seat, plug etc. cause students go to coffer shop more than library and also environment of library unable to attract student to come. Thus question was occurred, How to make library more than a ton of books storage. This research use SERVQUAL model to measure user's satisfaction integrated with Quality Function Deployment to create technical requirement for library improvement.

\section{THEORETICAL BACKGROUND}

\section{A. $\quad$ Service quality measurement}

Service quality framework, "Gap theory model" was developed by Parasuraman et.al. [6] which defined service quality as discrepancy between customer expectation for service and perception of service performance they received [7]. Concept of Gap theory model can be divided into 5 gaps [8] but this research focus on fifth gap, Expected serviceperceived service gap. More recently, service quality measurement scale with 22 items in 10 dimensions named SERVQUAL has been developed [9]. But finally SERVQUAL was concluded to be 5 dimensions scale [10]; Tangibles, Reliability, Responsiveness, Assurance and Empathy which widely using in present [11]-[17]. Definition of each dimension is explained by table I.

TABLE I

DEFINITION OF SERVQUAL DIMENSION

\begin{tabular}{|c|l|}
\hline Dimension & \multicolumn{1}{c|}{ Definition } \\
\hline Tangibles & $\begin{array}{l}\text { The appearance of physical facilities, } \\
\text { equipment, personnel and } \\
\text { communication materials }\end{array}$ \\
\hline Reliability & $\begin{array}{l}\text { The ability to perform the promised service } \\
\text { dependably and accurately }\end{array}$ \\
\hline Responsiveness & $\begin{array}{l}\text { The willingness to help customers and to } \\
\text { provide prompt service }\end{array}$ \\
\hline Assurance & $\begin{array}{l}\text { The knowledge and courtesy of employees } \\
\text { and their ability to convey trust and } \\
\text { confidence }\end{array}$ \\
\hline Empathy & $\begin{array}{l}\text { The provision of caring, individualized } \\
\text { attention to customers }\end{array}$ \\
\hline
\end{tabular}

\section{B. Quality Function Deployment}

Quality Function Deployment (QFD) was developed in 
Japan by Yoji Akao in 1966 [18]. After widespread in Japan, USA company took an interest in QFD and apply to USA business. QFD is an overall concept that provides a means of translating customer requirements into the appropriate technical requirements [19]. It is customer oriented approach for product development and support design process [20] by using customer needs, design requirements, target value, and competitive assessment [21] which widely applies to both manufacturing and service industries. In conclusion, we can say QFD is a systematic process for concentrate on customer needs [22].

One of QFD element is House of Quality (HOQ) which using planning matrix to relate customer needs to the method that leads to meet that needs [23]. Traditionally the customer needs, or "Voice of Customers (VOC)", are translated into quality characteristic correspondingly [24]. Figure 1 shows compositions of HOQ. The left room, "What" express customer needs and needs are translated into conformable "Hows" in the upper room below the "Roof". "Roof" display positive or negative relation of each "How" to other "How". After both "Hows" and "Whats" have been completely specified, next is to fill up correlation matrix in the middle room which display how much each "How" affect each "What". Finally priorities have been made for "Hows" at the bottom and for "Whats" on the right.

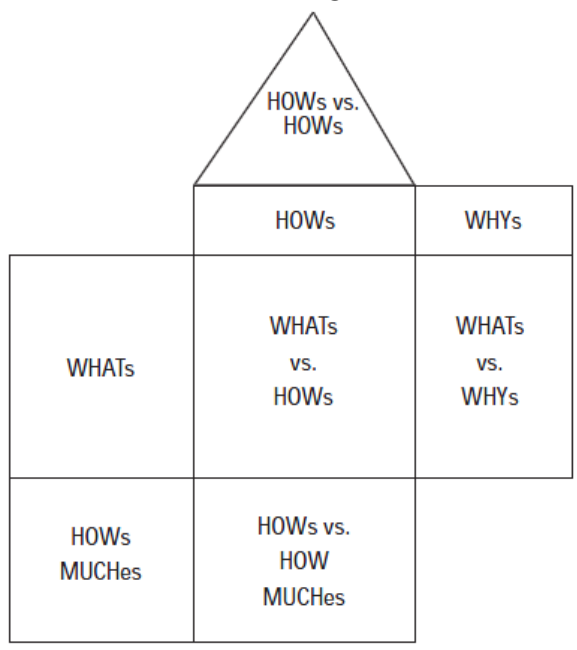

Fig. 1 The house of quality [25]

\section{Integration of SERVQUAL, QFD and Flower of} Service

House of Quality is commonly used matrix in Quality Function Deployment methodology [26]. Key to conduct HOQ is filling up left room or customer requirements (Whats) and upper room or design requirement (Hows) which many researchers frequently use others tools to define "Whats" and "How" [27],[28]. This research conducted SERVQUAL questionnaire to specify customer requirements and Flower of Service [29] to specify design requirements. Figure 2 showed

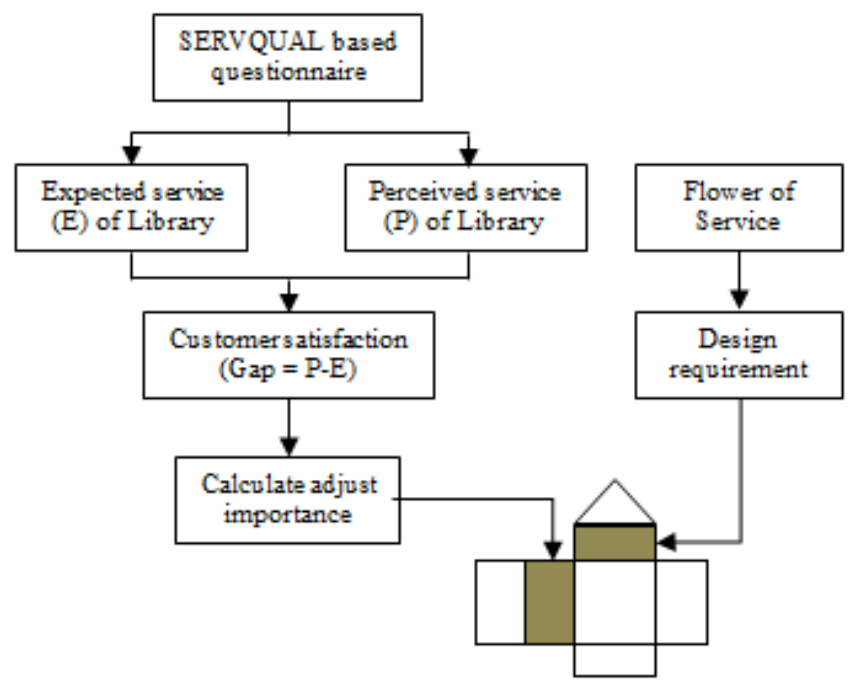

Fig. 2 Integration of SERVQUAL, QFD and Flower of Service framework

\section{METHODOLOGY}

Methodology of this research is an integration of SERVQUAL model, Quality Function Deployment and Flower of Service concept for finding out customer requirements to improve library service quality. Figure 3 demonstrate process of this research since questionnaire design, collecting information, conduct House of Quality and information analysis till the result come out.

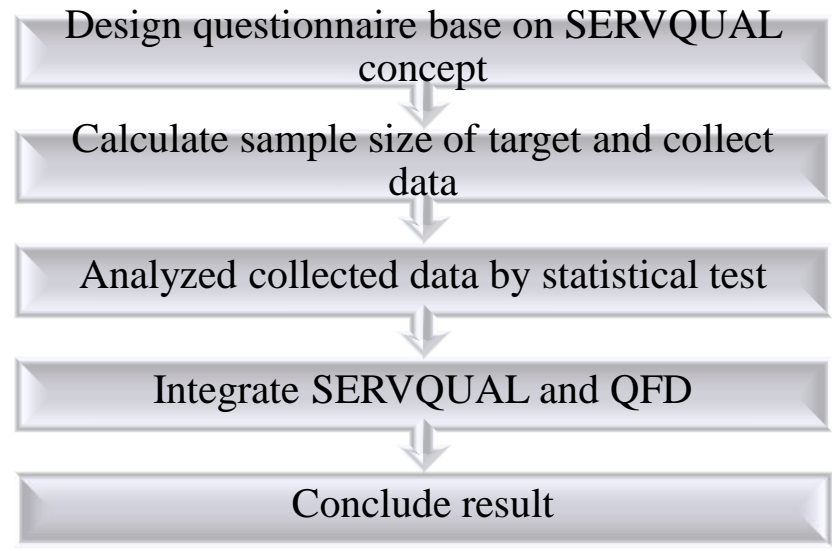

Fig. 3 Process steps for identifying library service quality

\section{Questionnaire design base on SERVQUAL concept}

Firstly, we need to conduct questionnaire for collecting data of library customer. SERVQUAL concept was used in conducting questionnaire to analyze customer satisfaction base on customer expectation and perception. 19 questions were created in 5 dimension of SERVQUAL model in 5 points Likert scale [30] together with screening questions to avoid bias data from people who not experienced in library service. After questionnaire was created as exhibit in Table II, it was examined by 3 specialists in library service to validate questionnaire before execution. Result of validation is IOC score of each questions are over 0.5 , thus questionnaire is capable to execute. 
TABLE II

SERVQUAL BASED QUESTIONNAIRE

\begin{tabular}{|c|c|c|}
\hline $\begin{array}{l}\text { SERVQUAL } \\
\text { dimension }\end{array}$ & Code & Question detail \\
\hline \multirow{8}{*}{ Tangible } & $\mathrm{T} 1$ & $\begin{array}{l}\text { Library has sufficient seats and } \\
\text { tables }\end{array}$ \\
\hline & $\mathrm{T} 2$ & $\begin{array}{l}\text { Library has extensive books and } \\
\text { journal for research }\end{array}$ \\
\hline & $\mathrm{T} 3$ & $\begin{array}{l}\text { Library has up-to-date information } \\
\text { exploring system }\end{array}$ \\
\hline & $\mathrm{T} 4$ & $\begin{array}{l}\text { Library has sufficient information } \\
\text { exploring equipments }\end{array}$ \\
\hline & T5 & $\begin{array}{l}\text { Library information exploring } \\
\text { equipments are in good condition }\end{array}$ \\
\hline & T6 & Library has tranquil environment \\
\hline & $\mathrm{T} 7$ & $\begin{array}{l}\text { Library has sufficient facilities ex. } \\
\text { Plug, iPad, Internet }\end{array}$ \\
\hline & T8 & Library has sufficient study room \\
\hline \multirow{4}{*}{ Reliability } & RE9 & $\begin{array}{l}\text { Books borrow-return is fast and } \\
\text { accurate }\end{array}$ \\
\hline & RE10 & $\begin{array}{l}\text { Books and journals arrange for } \\
\text { convenient searching }\end{array}$ \\
\hline & RE11 & $\begin{array}{l}\text { Library website provide useful } \\
\text { information and well functioning }\end{array}$ \\
\hline & RE12 & $\begin{array}{l}\text { Librarian provide fast and accurate } \\
\text { information }\end{array}$ \\
\hline \multirow{2}{*}{ Responsiveness } & RES13 & $\begin{array}{l}\text { Librarian provide prompt service to } \\
\text { customers }\end{array}$ \\
\hline & RES14 & $\begin{array}{l}\text { Librarian always willing to help } \\
\text { customers }\end{array}$ \\
\hline \multirow{3}{*}{ Assurance } & A15 & Customers trust librarians \\
\hline & A16 & $\begin{array}{l}\text { Librarians are courteous to } \\
\text { customers }\end{array}$ \\
\hline & A17 & $\begin{array}{l}\text { Librarians have knowledge to } \\
\text { answer question }\end{array}$ \\
\hline \multirow{2}{*}{ Empathy } & E18 & $\begin{array}{l}\text { Librarians understand specific need } \\
\text { of customers }\end{array}$ \\
\hline & E19 & $\begin{array}{l}\text { Librarians keep students' interest at } \\
\text { heart }\end{array}$ \\
\hline
\end{tabular}

\section{Statistical data analysis}

After collecting data, service quality was measure by customer perception score and expectation score from 19 questions in 5 dimensions though following formula:

Service quality $=$ Perception score $(\mathrm{P})-$ Expectation score $(\mathrm{E})$

When result is negative indicates customer has expectation in service more than he/she perceived or library services cannot meet customer expectation means customer is unsatisfied. In opposition, positive result indicates library services meet customer expectation or customer received service better than he/she expected. Mean of expectation score of each question in each customer were calculated. Then 19 questions mean scores were classified by SERVQUAL dimension and calculate mean again into 5 grand means. This 5 grand means represent expectation score of dimensions. Repeat process again for perception score result in 5 grand means that represent perception score of dimensions and conduct comparison by radar chart as Figure 5: Statistical pair t-test was conducted with $95 \%$ confident level to make certain of service quality in of each dimension is significantly different. Input data to Minitab program to test each dimension perception versus expectation score.

\section{RESULT AND DISCUSSION}

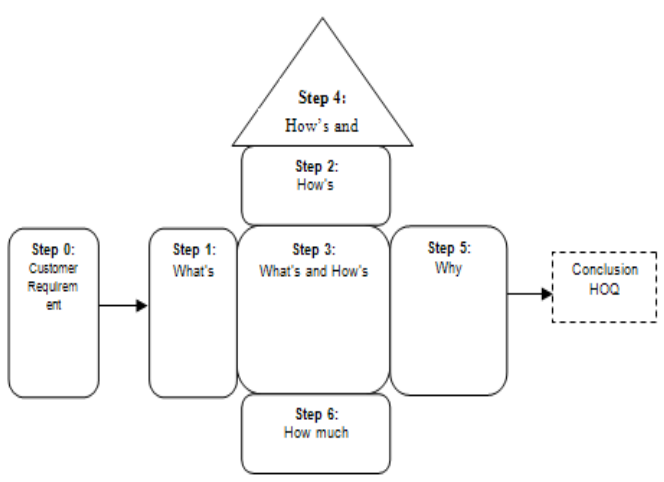

Fig. 3 Steps to Create the House of Quality[31]

\section{Step 0: Customer Requirement}

The process of Quality Function Deployment with 6 total Steps is shown in Figure 6. First step of QFD is to identify customer need or voice of customer. SERVQUAL based questionnaire was design to collect customer data Nineteen questions were created in fives dimension of SERVQUAL model in 5 points Likert scale together with screening questions to avoid bias data from people who not experienced in library service Then questionnaire was examined by 3 specialists in library service to validate questionnaire before execution. Result of validation is IOC score of each questions are over 0.5 , thus questionnaire is capable to execute.

Target group of this research is people in Chulalongkorn University engineering faculty; total 5,783 people. Simplified formula for proportions method [32],[33] was used to calculate sample size as formula below:

$$
n=\frac{N}{1+N e^{2}}
$$

$N$ refers to population size, $n$ refers to sample size and $e$ refers to acceptable sampling error which $95 \%$ confident level are assumed. Thus; $n=\frac{5783}{1+5783\left(0.05^{2}\right)} \approx 375$. Then 375 customers random sampling was used to collect data.

Step 1: What's

Customer requirement obtained from SERVQUAL based questionnaire. Nineteen questions became "What's" of House of Quality.

Then service quality expectations (SQE) were calculated by geometric mean method [34]. In case of Self state importance, all are filled by constant 1.00 to avoid bias on self evaluation. Adjust importance can be calculated as formula below:

Adjust importance $=\mathrm{SQE} *$ Self State Importance

Step 2:How's

Flower of Service concept which consists of core service and eight supplementary services (Information, Payment, Billing, Order-Taking, Consultation, Exception, Safekeeping and Hospitality) were used to create design requirements.

Each design requirement was specified improvement direction for developing by using symbols as below 
$7=$ Objective is to maximize

= Objective is to hit target

$1=$ Objective is to minimize

TABLE III

FLOWER OF SERVICE AND DESIGN REQUIREMENTS

\begin{tabular}{|c|l|}
\hline Service & \multicolumn{1}{|c|}{ Design requirements } \\
\hline \multirow{4}{*}{ Core service } & $\begin{array}{l}\text { Decrease books storage area, increase seating area } \\
\text { science }\end{array}$ \\
\cline { 2 - 3 } & Separate noisy zone and quiet zone \\
\cline { 2 - 3 } & $\begin{array}{l}\text { Increase facilities like plug, Wi-Fi stability and } \\
\text { speed }\end{array}$ \\
\hline \multirow{4}{*}{ Information } & Install LCD screen TV providing information \\
\cline { 2 - 3 } & Add online channel for inquiring information \\
\cline { 2 - 3 } & $\begin{array}{l}\text { Online searching and borrowing book or journal } \\
\text { program }\end{array}$ \\
\cline { 2 - 3 } & Book or journal reviewing service \\
\hline \multirow{3}{*}{ Order taking } & $\begin{array}{l}\text { Library has study room online reservation } \\
\text { program/application }\end{array}$ \\
\cline { 2 - 3 } & $\begin{array}{l}\text { Library has books or journal online reservation } \\
\text { program for loan }\end{array}$ \\
\hline Billing & Pay penalty by money top-up card \\
\hline Payment & $\begin{array}{l}\text { Library has specialist for giving information in } \\
\text { doing research }\end{array}$ \\
\hline \multirow{2}{*}{ Consultation } & Library has snack bar. \\
\hline \multirow{2}{*}{ Hospitality } & Library has iPad for loan \\
\cline { 2 - 2 } & Increase CCTV security \\
\hline Exception & Library has locker for customer possession deposit \\
\hline
\end{tabular}

Step 3: What's and How's

Correlations between customer requirements and design requirements were determined. Relationships were represent by number as below:

$$
\begin{aligned}
" 1 " & =\text { weak relation, } \\
" 3 " & =\text { moderate relation, } \\
" 9 " & =\text { strong relation } \\
\text { Blank } & =\text { no relationship between them }
\end{aligned}
$$

Step 4: How's and How's

At the roof top of HOQ is correlations between each design requirement which show how one design requirement effect to others. Correlations are presented by symbols as follow:

$$
\begin{aligned}
& “ \odot ”=\text { very positive relationship } \\
& “ \bigcirc "=\text { positive relationship } \\
& “ X ”=\text { negative relationship } \\
& \text { “ } "=\text { very negative relationship } \\
& \text { Blank = no relationship }
\end{aligned}
$$

Step 5: Why

On the right-hand side of the House of Quality is used for strategic planning because it contains information about the survey of customers' opinions between the product / service of competitors and ours. In case of engineering library of Chulalongkorn University, our competitors are Faculty of Political Science, Chulalongkorn University, Thailand and Thailand Knowledge Park (TK Park). Method of benchmarking is using SERVQUAL questionnaire 50 sets to collect data of two competitors. Average perception score of

\begin{tabular}{|c|c|c|c|c|}
\hline Code & Customer requirement & 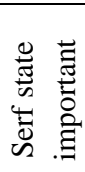 & SQE & 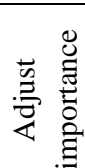 \\
\hline $\mathrm{T} 1$ & $\begin{array}{l}\text { Library has sufficient seats and } \\
\text { tables }\end{array}$ & 1.00 & 1.14 & 1.14 \\
\hline $\mathrm{T} 2$ & $\begin{array}{l}\text { Library has extensive books } \\
\text { and journal for research }\end{array}$ & 1.00 & 1.13 & 1.13 \\
\hline $\mathrm{T} 3$ & $\begin{array}{l}\text { Library has up-to-date } \\
\text { information exploring system }\end{array}$ & 1.00 & 1.23 & 1.23 \\
\hline $\mathrm{T} 4$ & $\begin{array}{l}\text { Library has sufficient } \\
\text { information exploring } \\
\text { equipments }\end{array}$ & 1.00 & 1.18 & 1.18 \\
\hline T5 & $\begin{array}{l}\text { Library information exploring } \\
\text { equipments are in good } \\
\text { condition }\end{array}$ & 1.00 & 1.16 & 1.16 \\
\hline T6 & $\begin{array}{l}\text { Library has tranquil } \\
\text { environment }\end{array}$ & 1.00 & 1.35 & 1.35 \\
\hline $\mathrm{T} 7$ & $\begin{array}{l}\text { Library has sufficient facilities } \\
\text { ex. Plug, iPad, Internet }\end{array}$ & 1.00 & 1.20 & 1.20 \\
\hline $\mathrm{T} 8$ & $\begin{array}{l}\text { Library has sufficient study } \\
\text { room }\end{array}$ & 1.00 & 1.22 & 1.22 \\
\hline RE9 & $\begin{array}{l}\text { Books borrow-return is fast and } \\
\text { accurate }\end{array}$ & 1.00 & 1.04 & 1.04 \\
\hline RE10 & $\begin{array}{l}\text { Books and journals arrange for } \\
\text { convenient searching }\end{array}$ & 1.00 & 1.07 & 1.07 \\
\hline RE11 & $\begin{array}{l}\text { Library website provide useful } \\
\text { information and well } \\
\text { functioning }\end{array}$ & 1.00 & 1.10 & 1.10 \\
\hline RE12 & $\begin{array}{l}\text { Librarian provide fast and } \\
\text { accurate information }\end{array}$ & 1.00 & 1.04 & 1.04 \\
\hline E18 & $\begin{array}{l}\text { Librarians understand specific } \\
\text { need of customers }\end{array}$ & 1.00 & 1.04 & 1.04 \\
\hline E19 & $\begin{array}{l}\text { Librarians keep students' } \\
\text { interest at heart }\end{array}$ & 1.00 & 1.05 & 1.05 \\
\hline
\end{tabular}
each question of our library, Political Science library and TK Park. Conduct both competitors average perception score divide by our library perception score become of comparison ratio that present how much different between our perceived service and competitors. Table 6 displays perception of our and competitor, include the ratios.

TABLE V

ADJUST IMPORTANCE 
TABLE VI

\begin{tabular}{|c|c|c|c|c|c|c|}
\hline \multicolumn{2}{|r|}{ Customer requirement } & 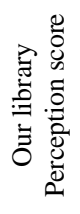 & 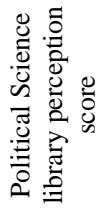 & 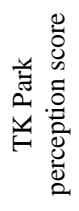 & 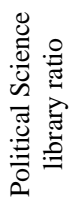 & 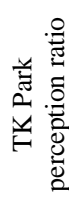 \\
\hline \multirow{8}{*}{ 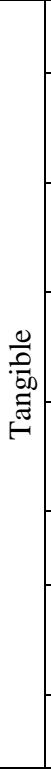 } & $\begin{array}{l}\text { Library has sufficient } \\
\text { seats and tables }\end{array}$ & 3.67 & 3.53 & 3.14 & 0.96 & 0.86 \\
\hline & $\begin{array}{l}\text { Library has extensive } \\
\text { books and journal for } \\
\text { research }\end{array}$ & 3.48 & 3.94 & 3.65 & 1.13 & 1.05 \\
\hline & $\begin{array}{l}\text { Library has up-to-date } \\
\text { information exploring } \\
\text { system }\end{array}$ & 3.16 & 3.68 & 3.69 & 1.17 & 1.17 \\
\hline & $\begin{array}{l}\text { Library has sufficient } \\
\text { information exploring } \\
\text { equipments }\end{array}$ & 3.29 & 3.66 & 3.50 & 1.11 & 1.06 \\
\hline & $\begin{array}{l}\text { Library information } \\
\text { exploring equipments } \\
\text { are in good condition }\end{array}$ & 3.43 & 3.80 & 3.63 & 1.11 & 1.06 \\
\hline & $\begin{array}{c}\text { Library has tranquil } \\
\text { environment }\end{array}$ & 3.09 & 2.78 & 3.57 & 0.90 & 1.15 \\
\hline & $\begin{array}{c}\text { Library has sufficient } \\
\text { facilities ex. Plug, iPad, } \\
\text { Internet }\end{array}$ & 3.46 & 3.38 & 3.54 & 0.98 & 1.02 \\
\hline & $\begin{array}{l}\text { Library has sufficient } \\
\text { study room }\end{array}$ & 3.39 & 2.70 & 3.18 & 0.80 & 0.94 \\
\hline \multirow{4}{*}{ 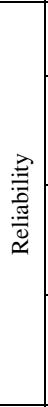 } & $\begin{array}{l}\text { Books borrow-return is } \\
\text { fast and accurate }\end{array}$ & 3.82 & 4.13 & 3.89 & 1.08 & 1.02 \\
\hline & $\begin{array}{c}\text { Books and journals } \\
\text { arrange for convenient } \\
\text { searching }\end{array}$ & 3.70 & 4.09 & 3.69 & 1.11 & 1.00 \\
\hline & $\begin{array}{l}\text { Library website provide } \\
\text { useful information and } \\
\text { well functioning }\end{array}$ & 3.42 & 4.03 & 3.74 & 1.18 & 1.09 \\
\hline & $\begin{array}{l}\text { Librarian provide fast } \\
\text { and accurate } \\
\text { information }\end{array}$ & 3.77 & 4.06 & 3.61 & 1.08 & 0.96 \\
\hline \multirow{2}{*}{ 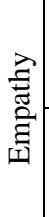 } & $\begin{array}{l}\text { Librarians understand } \\
\text { specific need of } \\
\text { customers } \\
\end{array}$ & 3.88 & 3.99 & 3.46 & 1.03 & 0.89 \\
\hline & $\begin{array}{l}\text { Librarians keep } \\
\text { students' interest at } \\
\text { heart }\end{array}$ & 3.87 & 4.00 & 3.56 & 1.03 & 0.92 \\
\hline
\end{tabular}

Step 6: How much

At the bottom of the House of Quality is used in addressing absolute weight and relative weight of each design requirement by calculated from correlation matrix which was created in step 3. Calculating formulas are as below:

$$
\begin{gathered}
\text { Absolute weight }=\sum(\text { Interrelationship*adjust importance }) \\
\text { Relative weight }=\frac{\text { Absolute Weight }}{\sum \text { Absolute Weight }} * 100 \\
\text { V. } \quad \text { CONCLUSION }
\end{gathered}
$$

Result of SERVQUAL based surveys method together with statistical test showed most 3 dimensions that have biggest gap were Tangible, Reliability and Empathy. Integration of SERVQUAL, QFD and Flower of service provide design requirements that response to customer requirements. Attractive design requirement are (1) online searching and borrowing book or journal program. (2) Increase facilities like plug, Wi-Fi stability and speed. (3) Library has books or journal online reservation program for loan.

The integration approach provides value that using each method alone cannot afford appropriate outcome. Customers gain advantage from this research as library understands requirement directly from customer and provide guidance for future research how to obtain and design what customers want. Furthermore, valid conducting in design process by integrating other tools will be road map to other research.

For further research, focusing on external customer like other university student or working people might bring out different customer requirements. Wider target group enhance library into international or global learning center.

\section{REFERENCES}

[1]M. E. Macken, "The Art Library As Place: The Role Of Current Space Planning Paradigms Within The Academic Art And Architecture Library," Art Documentation, Vol. 25, 2006.

[2]J. Reynolds And J. B. Whitlatch, "Academic Library Services: The Literature Of Innovation," In College And Research Libraries, Vol. 46, 1985.

[3]S. Gardner And S. Eng, "What Students Want: Generation Y And The Changing Function Of The Academic Library," Libraries And The Academy, Vol. 5, Pp. 405-420, 2005. http://dx.doi.org/10.1353/pla.2005.0034

[4]S. Gibbons, "Growing Competition For Libraries," Library Hi Tech, Vol. 19, P. 363 $\pm 367,2001$.

[5]N. Nimsomboon And H. Nagata, "Assessment Of Library Service Quality At Thammasat University Library System," 2003.

[6]A. Parasuraman, V. A. Zeithaml, And L. L. Berry, "A Conceptual Model Of Service Quality And Its Implications For Future Research," Journal Of Marketing, Vol. 49, Pp. 41-50, Fall 1985. http://dx.doi.org/10.2307/1251430

[7]P. Wongrukmit, "Hospital Service Quality Preference Mong Culture Diversity Based On Modified Servqual And Kano's Model," Presented At The 16th Qmod-Icqss, Korea, 2013.

[8]A. Shahin And M. Samea, "Developing The Models Of Service Quality Gaps: A Critical Discussion," Business Management And Strategy, Vol. $1,2010$.

[9]A. Parasuraman, V. A. Zeithaml, And L. L. Berry, "Servqual: A MultipleItem Scale For Measuring Consumer Perceptions Of Service Quality," Journal Of Retailing, Vol. 64, Pp. 12-40, //Spring 1988.

[10]A. Parasuraman, L. L. Berry, And V. A. Zeithaml, "Perceived Service Quality As A Customer-Based Performance Measure: An Empirical Examination Of Organizational Barriers Using An Extended Service Quality Model," Human Resource Management, Vol. 30, Pp. 335-364, 1991. http://dx.doi.org/10.1002/hrm.3930300304

[11]R. E. Reidenbach And B. Sandifer-Smallwood, "Exploring Perceptions Of Hospital Operations By A Modified Servqual Approach," Journal Of Health Care Marketing, Vol. 10, Pp. 47-55, 1990.

[12]H. Kang And G. Bradley, "Measuring The Performance Of It Services: An Assessment Of Servqual," International Journal Of Accounting Information Systems, Vol. 3, Pp. 151-164, 10// 2002.

[13]K. Yousapronpaiboon, "Servqual: Measuring Higher Education Service Quality In Thailand," Procedia - Social And Behavioral Sciences, Vol. 116, Pp. 1088-1095, 2/21/ 2014.

[14]G. J. Udo, K. K. Bagchi, And P. J. Kirs, "Using Servqual To Assess The Quality Of E-Learning Experience," Computers In Human Behavior, Vol. 27, Pp. 1272-1283, 2011. http://dx.doi.org/10.1016/j.chb.2011.01.009

[15]S. S. Andaleeb, "Service Quality Perceptions And Patient Satisfaction: A Study Of Hospitals In A Developing Country," Social Science \& Medicine, VoL. 52, PP. 1359-1370, 2001

http://dx.doi.org/10.1016/S0277-9536(00)00235-5 
[16]H. Lee, L. M. Delene, M. A. Bunda, And C. Kim, "Methods Of Measuring Health-Care Service Quality," Journal Of Business Research, Vol. 48, Pp. 233-246, 6// 2000.

[17]N. M. Suki, J. C. C. Lian, And N. M. Suki, "Do Patients' Perceptions Exceed Their Expectations In Private Healthcare Settings?," International Journal Of Health Care Quality Assurance, Vol. 24, Pp. 42-56, 2011. http://dx.doi.org/10.1108/09526861111098238

[18]S. Mizuno, Y. Akao, And K. Ishihara, "Qfd: Customer-Driven Approach," Taylor \& Francis, 1994.

[19]O. Pentelescu, "Using Quality Function Deployment In Food Industry," Bulletin Of University of Agricultural Sciences And Veterinary Medicine Cluj-Napoca. Agriculture, Vol. 65, 2008.

[20]K. Matzler And H. H. Hinterhuber, "How To Make Product Development Projects More Successful By Integrating Kano's Model Of Customer Satisfaction Into Quality Function Deployment," Technovation, Vol. 18, Pp. 25-38, 1// 1998.

[21]W. E. Eureka And N. E. Ryan, The Customer-Driven Company: Managerial Perspective On Quality Function Deployment: Asi Press, 1994.

[22]S. Sahney, D. K. Banwet, And S. Karunes, "A Servqual And Qfd Approach To Total Quality Education," International Journal Of Productivity And Performance Management, Vol. 53, Pp. 143-166, 2004. http://dx.doi.org/10.1108/17410400410515043

[23]Q. Yang, S. Yang, Y. Qian, And A. Kraslawski, "Application Of House Of Quality In Evaluation Of Low Rank Coal Pyrolysis Polygeneration Technologies," Energy Conversion And Management, Vol. 99, Pp. 231$241,7 / 15 / 2015$.

[24]B. K. Jayaswal And P. C. Patton, Design For Trustworthy Software: Tools, Techniques, And Methodology Of Developing Robust Software: Pearson Education, 2006.

[25]B. Prasad, "Synthesis Of Market Research Data Through A Combined Effort Of Qfd, Value Engineering, And Value Graph Techniques," Qualitative Market Research: An International Journal, Vol. 1, Pp. 156172, 1998. http://dx.doi.org/10.1108/13522759810235250

[26]Z. Yu, "Analyzing Service Quality Via Qfd And Servqual: Applications In Accommodation Services And Distance Learning," 2004.

[27]A. K. Ikiz And A. Masoudi, "A Qfd And Servqual Approach To Hotel Service Design," Dokuz Eylül Üniversitesi İşletme Fakültesi Dergisi, Vol. 9, 2008.

[28]M. L. Singgih And N. Ardhiyani, "Integrating Servqual With Kano Into Quality Function Deployment (Qfd) For Better Quality Of Services Case Study: Pt Pos Indonesia, Branch Office Of Sidoarjo," In 2010 Informs Service Science Conference, 2010, Pp. 419-425.

[29]C. Lovelock, P. G. Patterson, And J. Wirtz, Services Marketing: Pearson Australia, 2014.

[30]J. G. Dawes, "Do Data Characteristics Change According To The Number Of Scale Points Used? An Experiment Using 5 Point, 7 Point And 10 Point Scales," International Journal Of Market Research, Vol. 51, 2008.

[31]W. Yothinsirikul And N. Thawesaengskulthai, "Application Of Quality Function Deployment And Servqual For Design Service Innovation," Pp. 12-21, 2014.

[32]T. Yamane, Statistics: An Introductory Analysis, 2nd Edition: Newyork: Harper And Row, 1973.

[33]G. Molenberghs, Survey Methods And Sampling Techniques, 2010.

[34]G. Crawford, "The Geometric Mean Procedure For Estimating The Scale Of A Judgement Matrix," Mathematical Modelling, Vol. 9, Pp. 327-334, 1987.

http://dx.doi.org/10.1016/0270-0255(87)90489-1 


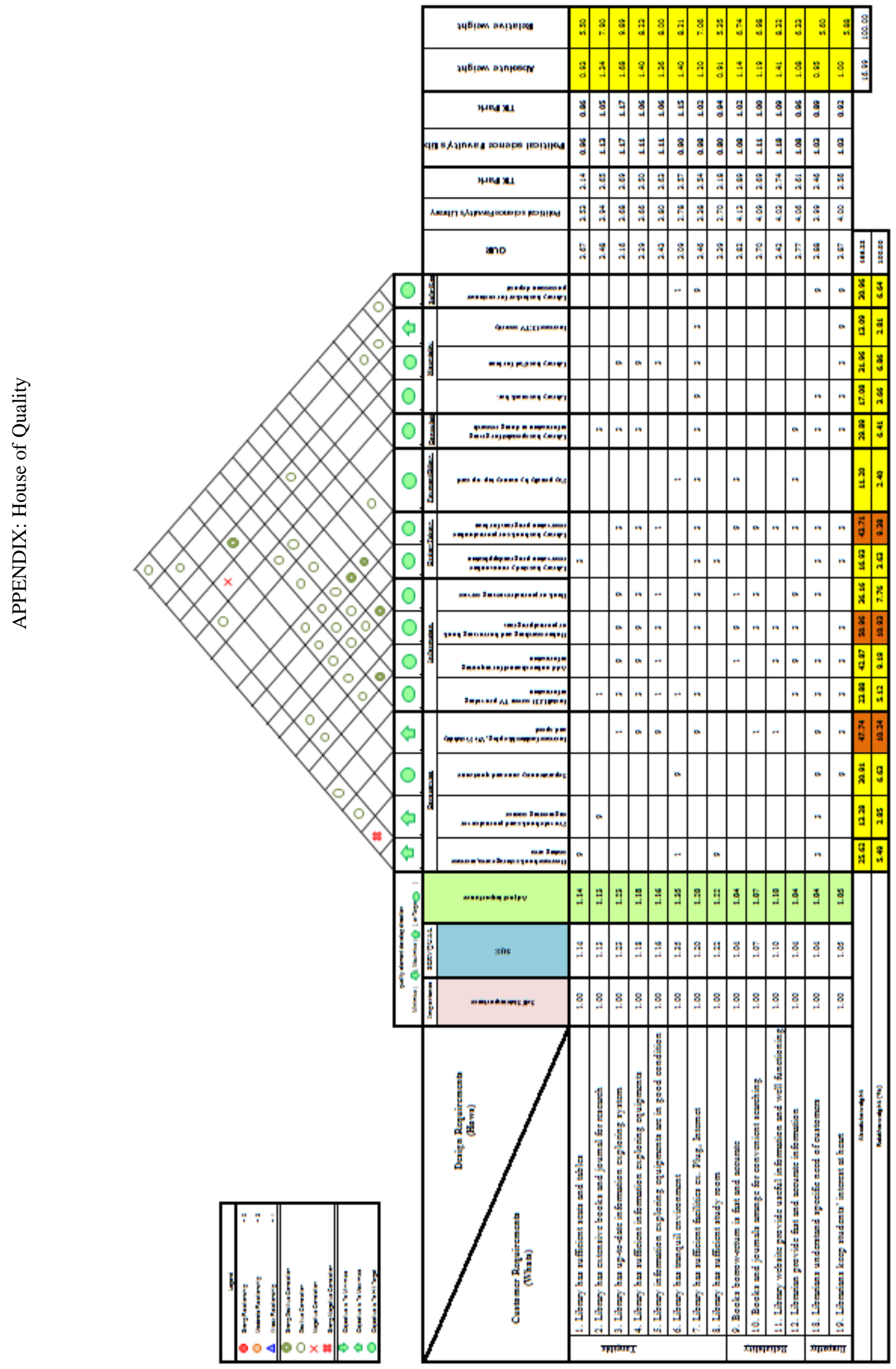

